\title{
Repeatability and genotypic stability of agronomic characteristics in Panicum maximum Jacq.
}

\author{
Mariane Rodrigues Ferreira ${ }^{*}$, Janaina Azevedo Martuscello², Thiago Gomes dos Santos Braz ${ }^{3}$, \\ Artur Amaral Nascimento ${ }^{4}$, Liana Jank ${ }^{5}$, Juliana Aparecida de Assis ${ }^{6}$, Otávio Goulart de Almeida, \\ Gabriel de Assis Reis ${ }^{6}$, Márcia Vitória Santos ${ }^{7}$, and Mateus Figueiredo Santos ${ }^{5}$
}

\begin{abstract}
${ }^{1}$ Universidade Estadual Paulista, Via de Acesso Prof. Paulo Donato Castelane, Castellane s/n, Vila Industrial, Jaboticabal, São Paulo, Brasil. "Corresponding author (mariane_candeias@hotmail.com).

${ }^{2}$ Universidade Federal de São João del-Rei, Avenida Visconde do Rio Preto, s/n, Colônia do Bengo, São João del-Rei, Minas Gerais, Brasil.

${ }^{3}$ Universidade Federal de Minas Gerais, Avenida Universitária 1000, Bairro Universitário, Montes Claros, Minas Gerais, Brasil.

${ }^{4}$ Universidade Estadual do Sudoeste da Bahia, Praça Primavera, 40, Bairro Primavera, Itapetinga, Bahia, Brasil.

${ }^{5}$ Embrapa Gado de Corte, Empresa Brasileira de Pesquisa Agropecuária, Campo Grande, Mato Grosso do Sul, Brasil.

${ }^{6}$ Universidade de São Paulo, Av. Pádua Dias 11, Cx. Postal 9, Piracicaba, São Paulo, Brasil.

${ }^{7}$ Universidade Federal dos Vales do Jequitinhonha e Mucuri, Rodovia MGT $367-\mathrm{km} \mathrm{583,} \mathrm{n} 5000$, Alto da Jacuba, Diamantina, Minas Gerais, Brasil.
\end{abstract}

Received: 12 March 2019; Accepted: 23 July 2019; doi:10.4067/S0718-58392019000400547

\begin{abstract}
In experiments with selection of perennial plants, the initial performance is expected to be maintained throughout the productive life. The probability of repeating the agronomic response can be evaluated by the repeatability coefficient. The objective was to estimate repeatability coefficients of agronomic characteristics in Panicum maximum Jacq. using different methods and identify the best combinations between harvests according to the genotypic stabilization. Seventeen genotypes were evaluated in a randomized complete block design with three replicates. The coefficients of repeatability were estimated by the methods: ANOVA, structural analysis based on the mean of the correlation coefficients (SACOR), analysis of principal components based on the covariance matrix (PCCOV) and correlation matrix (PCCOR). In the genotypic stabilization, coefficients estimated by ANOVA and PCCOR were used. For total DM, repeatability coefficients ranged from 0.3500 to 0.4300 by the ANOVA and PCCOR methods, respectively. High repeatability coefficients were found for the characteristic leaf DM, while low coefficients were observed for leaf and stem percentages and leaf:stem ratio. For the genotypic stabilization of total DM and leaf:stem ratio, the best coefficients were observed for the combination of harvests 5 to 8 . There are variations in the estimate of repeatability by different methods and the highest coefficients were those of the principal components based on the correlation and covariance matrices. For the genotypic stabilization, the best coefficients of repeatability and determination were observed for the harvests performed in the second rainy period.
\end{abstract}

Key words: Forage, leaf:stem ratio, repeated measures.

\section{INTRODUCTION}

Livestock production on pastures corresponds to a large portion of the Brazilian agribusiness, generating income and jobs. This is due to the extensive territory established with pastures and soil and climatic conditions favorable to the use of tropical forages. Among the plants mostly used in pasture formation, Panicum maximum Jacq., characterized by high forage production, good nutritional value and good response to fertilization (Jank et al., 2014) is noteworthy. 
Most P. maximum plants, especially the registered cultivars, reproduced by apomixis, in which the new plant has the same characteristics as the mother plant. This type of reproduction makes Brazilian pastures be considered extensive monocultures of high genetic vulnerability (Valle et al., 2009), making them susceptible to biotic and abiotic stresses (Fernandes et al., 2014). In this scenario, the diversification process is indispensable for the increase in genetic variability, while providing forages more adapted to a certain region, further improving its yield potential.

For the selection of P. maximum genotypes, a perennial cycle plant, regular evaluations are necessary, by successive harvests, being able to estimate the genotypic variability and the repeatability of the response of a certain characteristic. When performing successive harvests, it is possible to estimate the coefficient of repeatability of the evaluated characteristics, that is, to measure the probability or the capacity of these characteristics to repeat throughout the evaluations. Repeatability is an important genetic parameter in breeding studies and in the evaluation process of forage plants (Jank et al., 2014).

Genotypic stabilization studies are also important tools in the evaluation of perennial crops, since during the first harvests, when the plants are still young, a low expression of genes which are important for critical characteristics in the productive phase may occur (Pereira et al., 2002) and thus jeopardize the evaluation process. In addition, the establishment of forages in the field and the change in management in early phases of the research may also result in differential expression of genes that modify the productive response and lead to errors in the evaluation process (Braz et al., 2015a).

In genotypic stabilization works, repeatability coefficients of groups of successive harvests are estimated, indicating periods where there are greater correlations among repeated measurements and, consequently, periods where there is greater reliability in the process of selection of genotypes.

Thus, the objective of this study was to estimate repeatability coefficients of agronomic characteristics in P. maximum genotypes by different methods and identify the best combinations between harvests according to the genotypic stabilization.

\section{MATERIAL AND METHODS}

The experiment was conducted in São João del-Rei in Campo das Vertentes $\left(21^{\circ} 08^{\prime} 11^{\prime \prime}\right.$ S, 40 $40^{\circ} 43^{\prime}$ ” W; 904 m a.s.1.), Minas Gerais, Brazil. According to classification of Köppen, climate is Cwa type, with well defined dry (May to October) and rainy seasons (November to April). Data on mean, maximum and minimum temperatures and precipitation during the experimental period are presented on Figure 1.

Seventeen Panicum maximum Jacq. genotypes (accessions B57, B53, PM21, PM35, PM41, PM122, PM114, A78, PM22, PM7, B46, C12, B11, C53, B55, PM6 and cv. BRS Quênia), which are part of the breeding program at Embrapa Beef Cattle were used. The design was randomized blocks with three replicates. Nine harvests were performed during the 2 yr evaluation period.

Before the implementation of the experiment, the soil of the experimental area was collected and analyzed for chemical characteristics and presented the following results: $\mathrm{pH}$ in water ratio $(1: 2.5) 6.41 ; 5.8 \mathrm{mg} \mathrm{P} \mathrm{L}^{-1} ; 135 \mathrm{mg} \mathrm{K} \mathrm{L}^{-1} ; 4.08 \mathrm{cmol}_{\mathrm{c}} \mathrm{Ca}$ $\mathrm{L}^{-1} ; 0.84$ cmol $_{\mathrm{c}} \mathrm{Mg} \mathrm{L}^{-1} ; 0.00 \mathrm{cmol}_{\mathrm{c}} \mathrm{Al} \mathrm{L}{ }^{-1} ; \mathrm{H}+\mathrm{Al}=1.83$ cmol $_{\mathrm{c}} \mathrm{L}^{-1} ; 3.56 \mathrm{~g} \mathrm{~kg}^{-1}$ organic matter; $5.27 \mathrm{cmol}_{\mathrm{c}} \mathrm{L}^{-1}$ base sum $(\mathrm{Ca}+$ $\mathrm{Mg}+\mathrm{K}+\mathrm{Na}$ ); $7.1 \mathrm{cmol}_{\mathrm{c}} \mathrm{L}^{-1}$ cation exchange capacity in $\mathrm{pH} 7 ; 74.22 \%$ base saturation. Fifty kilograms of $\mathrm{P}_{2} \mathrm{O}_{5}$ in the form of simple superphosphate were applied to the soil prepared by the conventional method, before transplanting the seedlings.

The genotypes were evaluated in $4 \mathrm{~m}^{2}$ plots. To guarantee uniformity of the stand at the time of establishment, genotypes were previously sown in the greenhouse on 17 October 2014, on commercial agricultural substratum and transplanted to the experimental area $35 \mathrm{~d}$ after germination (11 November 2014) to assure a density of 30 seedlings $\mathrm{m}^{-2}$. Fertilization corresponding to $100 \mathrm{~kg} \mathrm{~N} \mathrm{ha}^{-1}$ in the form of urea was carried out $7 \mathrm{~d}$ after transplantation. On 22 December 2014, when plants completed $31 \mathrm{~d}$ in the field, a standardization cut was performed. After $44 \mathrm{~d}$, the first harvest was made (4 February 2015). On the total, seven harvests were performed during the rainy season and two harvests in the dry season. Harvests were done at $20 \mathrm{~cm}$ from soil in the useful area of the plot, discarding borders, on 4 February, 14 March, 14 May, 29 October, 23 December 2015 and 2 February, 14 March, 20 April and 23 September 2016. The interval between successive harvests was $42 \mathrm{~d}$ in the rainy season and $90 \mathrm{~d}$ in the dry season. After harvests, plots were fertilized with $\mathrm{N}$ and $\mathrm{K}$ at doses equivalent to $50 \mathrm{~kg} \mathrm{~N}$ ha $^{-1}$ (45 $\mathrm{g}$ urea in each plot) and $20 \mathrm{~kg} \mathrm{~K}_{2} \mathrm{O} \mathrm{ha}^{-1}(13 \mathrm{~g} \mathrm{KCl}$ in each plot) two times in the rainy season. 
Figure 1. Cumulative precipitation (Prec.) and maximum (Max), minimum (Min) and average temperatures recorded during the experimental period.

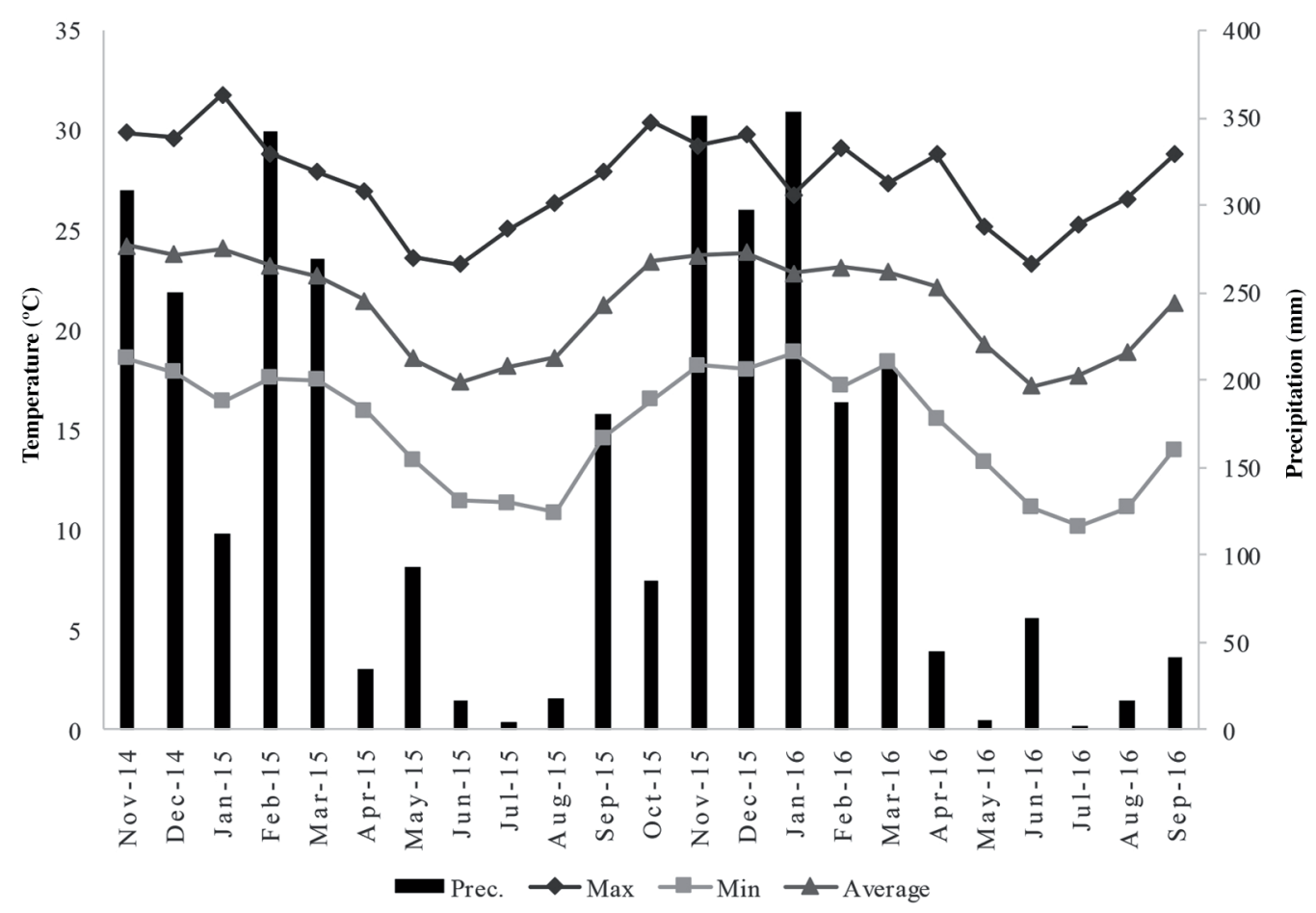

Source: Instituto Nacional de Meteorologia (INMET), Brasília-DF, Brazil.

The forage harvested in the useful area $\left(1 \mathrm{~m}^{2}\right.$ in the center) was weighted to obtain the forage fresh matter and then separated in two samples. The first one was dried in an air forced oven at $55^{\circ} \mathrm{C}$ for $72 \mathrm{~h}$, grounded $(1 \mathrm{~mm}$ sieve $)$ and definitely dried at $105^{\circ} \mathrm{C}$ during $24 \mathrm{~h}$ to determine the DM content. The second sample was separated in fractions: leaves, leaf sheath + stems and senescent matter. These values were used to determine leaf percentage $(\% \mathrm{~L})$, stem percentage $(\%$ S), leaf:stem ratio (LSR), leaf DM (LDM) and stem DM (SMD).

The coefficients of repeatability were estimated using four methods: ANOVA, analysis of principal components based on the covariance matrix (PCCOV), analysis of principal components based on the correlation matrix (PCCOR), and structural analysis based on the mean of the correlation coefficients (SACOR), according to the methodologies described in Cruz et al. (2004).

The basic model with two sources was used to stimate the repeatability coefficient $\left(\mathrm{Y}_{\mathrm{ij}}\right)$ by ANOVA method:

$$
\mathrm{Y}_{i j}=\mu+g_{i}+a_{j}+e_{i j}
$$

where, $\mu$ is general average; $g_{i}$ is effect of the genotype i under permanent environment influence; $a_{j}$ is fixed effect of the temporary environment in the $\mathrm{j}$ measurement; $e_{i j}$ is effect of the temporary environment associated with the $\mathrm{j}$ measurement in the i genotype. To this model, the coefficient was estimated by:

$$
r=\frac{\operatorname{cov}\left(\mathrm{Y}_{i j}, \mathrm{Y}_{i j}{ }^{\prime}\right)}{\sqrt{V\left(\mathrm{Y}_{i j}, \mathrm{Y}_{i j}{ }^{\prime}\right)}}=\frac{\hat{\sigma}_{g}^{2}}{\hat{\sigma}^{2}+\hat{\sigma}_{g}^{2}}
$$

where, $\hat{\sigma}_{g}^{2}$ is the covariance between repeated measures in each genotype and $\hat{\sigma}^{2}$ is the residual variance.

The principal component method estimates repeatability coefficient by two ways: i) using the phenotypic variance and covariance matrix and ii) using the phenotypic correlation matrix. The second was proposed by Abeywardena (1972) and is based on the estimation of the coefficient of correlation between repeated measures and subsequent obtention of the eigenvalue and eigenvector normalized. Among the estimated eigenvectors it is identified the one that has elements with the same signal and close magnitudes. This vector best expresses the tendency of genotypes to maintain their relative positions in the various periods of time. The coefficient could be estimated by: 


$$
r=\frac{\hat{\lambda}_{1}-1}{\eta-1}
$$

where $\hat{\lambda}_{1}$ is the eigenvalue of the correlation matrix associated to eigenvector with the same signal and close magnitudes and $\eta$ is the number of repeated measures.

The principal component method, based on variance and covariance matrix, estimates the repeatability coefficient with:

$$
r=\hat{\rho}=\frac{\hat{\lambda}_{1}-\hat{\sigma}_{Y}^{2}}{\hat{\sigma}_{Y}^{2}(\eta-1)}
$$

where $\hat{\lambda}_{1}$ is the eigenvalue of the phenotypic variance and covariance matrix associated to eigenvector with the same signal and close magnitudes, $\hat{\sigma}_{Y}^{2}=\hat{\sigma}_{g}^{2}+\hat{\sigma}_{\tilde{\sigma}}^{2}$ is the phenotypic variance of the characteristic Y.

The structural analysis method based on the correlation matrix uses:

$$
r=\frac{\hat{\alpha}^{\prime} R \hat{\alpha}-1}{\eta-1}
$$

where, $\hat{\alpha} R \hat{\alpha}$ is the eigenvalue $\left(\hat{\lambda}_{1}\right)$ of the phenotypic correlation matrix associated to the eigenvector with the same signal and close magnitudes; $\hat{\alpha}^{\prime}$ is the eigenvector associated to $\hat{\lambda}_{1}$; and $\hat{\alpha}^{\prime} \hat{\alpha}=1$.

The minimum number of repeated measures to improve the efficiency in the selection was estimated to $85 \%, 90 \%, 95 \%$ and $99 \%$ coefficients of determination $\left(\mathrm{R}^{2}\right)$ using:

$$
\eta_{o}=\frac{\mathrm{R}^{2}(1-\mathrm{r})}{\left(1-\mathrm{R}^{2}\right) \mathrm{r}}
$$

where, $\eta_{o}$ is the number of repeated measures necessary to obtain the desired coefficients of determination $\left(\mathrm{R}^{2}\right)$ and $r$ is the stimated coefficient of repeatability.

After the estimation of the coefficient of repeatability by the different methods, the genotypic stabilization analysis was performed. The coefficients estimated by ANOVA and PCCOR were used for consecutive measurements, considering 2, $3, \ldots$ until all $n$ evaluations were performed. Therefore, $n-1$ analyses of two consecutive measurements were performed; n-2 analyses of three consecutive evaluations until nine measurements were obtained (Cruz et al., 2004).

All analyses were carried out in the GENES program - Computational application in genetics and statistics, version 2016.6.0 (Cruz, 2013).

\section{RESULTS AND DISCUSSION}

The principal component methods provided the highest coefficients of repeatability, and the one obtained from the variance and covariance matrix (PCCOV) stood out in relation to the one obtained from the correlation matrix (PCCOR) (Table 1). Regardless of the evaluated characteristic, ANOVA, followed by the method of structural analysis based on the correlation matrix (SACOR) provided smaller values of the repeatability coefficients.

Variations observed may be associated with the methodology used to calculate the coefficient (Mansour et al., 1981). According to Abeywardena (1972), the repeatability coefficient can be more efficiently estimated through the principal components method, since this methodology emphasizes situations in which the evaluated genotypes present a cyclical

\begin{tabular}{|c|c|c|c|c|c|c|c|}
\hline \multirow{2}{*}{ Method } & & \multicolumn{6}{|c|}{ Characteristics } \\
\hline & & TDM & LDM & LSR & SDM & $\mathrm{S} \%$ & $\mathrm{~L} \%$ \\
\hline \multirow[t]{2}{*}{ ANOVA } & $\mathrm{r}$ & 0.3500 & 0.3496 & 0.1127 & 0.1954 & 0.1052 & 0.0852 \\
\hline & $\mathrm{R}^{2}$ & 82.89 & 82.87 & 53.33 & 68.61 & 51.41 & 45.60 \\
\hline \multirow[t]{2}{*}{ PCCOV } & $\mathrm{r}$ & 0.4196 & 0.5083 & 0.4477 & 0.4573 & 0.4528 & 0.4407 \\
\hline & $\mathrm{R}^{2}$ & 86.67 & 90.29 & 87.94 & 88.35 & 88.16 & 87.64 \\
\hline \multirow[t]{2}{*}{ PCCOR } & $\mathrm{r}$ & 0.4300 & 0.4527 & 0.3703 & 0.3509 & 0.4329 & 0.3122 \\
\hline & $\mathrm{R}^{2}$ & 87.16 & 88.15 & 84.10 & 82.94 & 87.29 & 80.33 \\
\hline \multirow[t]{2}{*}{ SACOR } & $\mathrm{r}$ & 0.4085 & 0.4347 & 0.2217 & 0.2195 & 0.2456 & 0.1568 \\
\hline & $\mathrm{R}^{2}$ & 86.13 & 87.37 & 71.93 & 71.68 & 74.55 & 62.60 \\
\hline
\end{tabular}

Table 1. Estimates of the coefficient of repeatability (r) and their respective coefficients of determination $\left(R^{2}\right)$ of the characteristics total dry mass production (TDM), leaf dry mass (LDM), leaf:stem ratio (LSR), stem dry mass (SDM), stem percentage $(\mathrm{S} \%)$, and leaf percentage $(\mathrm{L} \%)$.

ANOVA: Analysis of variance; PCCOV: principal components-covariance; PCCOR: principal componentscorrelation; SACOR: structural analysis-correlation. 
behavior. The ANOVA method, on the other hand, may not eliminate this additional component of the experimental error and, consequently, underestimate the repeatability coefficient. However, the structural analysis presents only conceptual differences from the principal components analysis, and the estimates of these methods tend to be close (Cruz et al., 2004).

Forage production in P. maximum shows production peaks during the rainy season, and a decrease during the dry season of the year, characterizing a cyclic response, mainly in the evaluation of repeatability of harvests. This effect may vary in different ways and intensities in each genotype. In fact, the seasonality of production of tropical forages is well known and according to Jank et al. (2011), some cultivars of $P$. maximum can present around $80 \%$ of production in the rainy season.

Martuscello et al. (2007), evaluating different methods to estimate the repeatability coefficient of agronomic characteristics in P. maximum, observed that the PCCOV method presented better results. According to the authors, in general, variations in the estimate of the repeatability coefficient indicate the need to use the several methods available to obtain an accurate range within which, more likely, the actual value for this parameter is found. The same response was also observed by Cargnelutti Filho et al. (2004), Braz et al. (2015b) and Fernandes et al. (2017) in P. maximum. Braz et al. (2015b) highlighted a large discrepancy between methods, which was attributed to the bias of the principal component analysis methods when the actual value of the coefficient approaches zero (Mansour et al., 1981).

For TDM, repeatability coefficients ranging from 0.350 to 0.430 were observed for the ANOVA and PCCOR methods, respectively. Regardless of the method used, the coefficient of determination was higher than 82.89 , indicating reliability in the identification of the best P. maximum genotypes for DM production (Table 1). Braz et al. (2015b), evaluating agronomic characteristics of different progenies of P. maximum in six harvests, found similar results to those of this study, and regardless of the method used, the authors found a coefficient of determination above 82.55. These results indicate that TDM evaluation requires a smaller number of repeated measures for a good level of reliability in the prediction of the response and identification of superior genotypes. Fernandes et al. (2017), estimating repeatability coefficients of TDM production in 24 genotypes of $P$. maximum, in 12 harvests, observed values varying from 0.259 to 0.413 , by the ANOVA and PCCOV methods, respectively. This amplitude was greater than that observed in this paper. On the other hand, Souza Sobrinho et al. (2010) found lower values of repeatability of TDM for Urochloa ruziziensis than those in this study, ranging from 0.23 to 0.25 for the ANOVA and PCCOR methods, respectively.

Higher repeatability coefficients were also found for LDM yield, and PCCOV method presented higher repeatability (0.5083) and determination (90.29) (Table 1). The TDM and LDM characteristics presented very close values. According to Braz et al. (2015b) this behavior can be explained by the large amount of leaves that is usually found in forage mass samples in P. maximum genotypes. Also, the fact that the genotypes evaluated in this study are considered to perform well for characteristics of interest in breeding, such as LDM, also contribute to this result. This is because the evaluated genotypes have already been previously selected in Embrapa's P. maximum breeding program. The coefficients observed in this study were lower than those reported in the literature for this species (Cargnelutti Filho et al., 2004; Lédo et al., 2008) and ranged from $0.542(93.90)$ to 0.869 (98.15). In this sense, the repeatability for LDM in this study may be considered low in relation to the literature reports.

LDM is indispensable in the process of selection of new forages, since leaves present greater digestibility in relation to stem (Freitas et al., 2012) and favor forage consumption by the grazing animals. In this sense, selection based on this characteristic tends to improve the efficiency of the breeding process, especially in the final stage, when the evaluation of the animal weight gain is the main indicator of the plant's potential utilization (Martuscello et al., 2007).

Leaf:stem ratio (LSR) presented repeatability coefficients close to SDM, ranging from 0.1127 by the ANOVA method to 0.4477 by the PCCOV method, considered low values (Table 1). Similar results were observed by Cargnelutti Filho et al. (2004) evaluating five genotypes of P. maximum with solar restriction, in which the authors found values of 0.080 and 0.528 by the ANOVA and PCCOV methods, respectively. This fact can be explained by the climatic variations over the years, considering that evaluations were carried out during the four seasons, where differences in climate occurs, such as high temperatures and precipitation during the summer and their decrease during dry and transition rainy-dry periods. In addition, LSR is also influenced by the phenological stage of the plants which, in turn, may interfere in the results when the evaluations are done at fixed periods of harvest as in this study. 
Stem dry mass (SDM) presented coefficients that varied from 0.1954 for the ANOVA method to 0.4573 for the PCCOV method. Probably this is due to the bias caused by the occurrence of lower repeatability coefficients from the methods based on principal component analyses, which tend to overestimate the value of the parameter under these conditions (Mansour et al., 1981). Torres et al. (2016) evaluating three P. maximum cultivars, in six harvests, found coefficients of repeatability and determination (in parentheses) of 0.52 (87) and 0.86 (97) for the ANOVA and PCCOV methods, respectively, which were higher than those found in this study. The importance of SDM in breeding is low, since this component is not intended for improvement of the production, but can be reduced by selecting plants that have the highest leaf percentage.

Low repeatability coefficients were estimated for leaf percentage (L\%), which presented values ranging from 0.0852 by the ANOVA method to 0.4407 by the PCCOV method (Table 1). This may be justified by the fact that the experiment lasted for two consecutive years, including periods of drought and transitions, periods in which the stem yields can vary greatly and, consequently, affect L\%. Lower repeatability coefficients for L\% were also observed by Braz et al. (2015b), who found mean values of 0.2498 for full-sib progenies of P. maximum. According to these authors, these results may be associated to the low degree of genetic control of the characteristic L\%, which is subject to environmental variation and tends to present a high coefficient of variation. Martuscello et al. (2007), working with half-sib progenies of P. maximum observed substantially greater repeatabilities for L\% (0.7067). These variations highlight the importance of new studies on this genetic parameter to subsidize further studies with evaluation of forage genotypes and repeated measures.

As with L\%, stem percentage (S\%) also presented lower values estimated by the ANOVA method (0.1052) and higher by PCCOV method (0.4528). Probably, these results are due to the marked effect of the level of maturity of plants in the participation of this component in the morphological composition of forage. In this sense, environmental control would exert a greater effect on S\% than genetic control, which would make the selection process more difficult. Nevertheless, simultaneous gains can be obtained by L\%, which presents a high and negative correlation with S\% (Braz et al., 2015b).

In the study of genotypic stabilization, the best repeatability and determination coefficients for the variable TDM were observed for the combination between harvests 6 to 7 and between harvests 5 to 8 , whereas the lowest coefficients were observed when only harvests 3 to 4 and 1 to 2 were used in both methods (Table 2). The improvement of the coefficients by the combination between harvests 6 to 7 and also, by the combination of harvests of 5 to 8 represent the evaluations made during the second rainy season after establishment. It is possible that harvests occurred from 5 to 8 represent uniform environmental conditions which improve the repeatability coefficient. A similar result was found in a study by Fernandes et al. (2017), in which the best coefficients of repeatability and determination were also observed for the harvests during the rainy season.

Another explanation to the higher repeatability in the second rainy season is the effect of successive harvests on the stabilization of plant response. Thus, in the begining of the trial, plants were not expressing the genes responsible for productive response, common of the adult stage. So, even if the first harvests have been made within the rainy season, genotypic stabilization was only achieved after entry into the second rainy period. It impacts directly the experimental management, since forage plants need longer periods of adaptation to the experimental conditions to have a more uniform response to the treatments.

We believe that after the first harvests ( 1 and 2 ) and the harvests of the first dry season ( 3 and 4), plants were already in a condition of more advanced physiological maturity or with full establishment of root system and aerial part, which led to greater uniformity of the response throughout successive defoliations. These conditions may represent the full expression of genes responsible for yield characteristics, so desired in the productive phase of forage plants, as discussed by Pereira et al. (2002) and Braz et al. (2015a).

In general, the inclusion of the first harvest and the harvests done during the dry season were detrimental to the estimate of the TDM repeatability, leading to low coefficients and the need for a greater number of repeated measures to improve efficiency in selection and prediction of the agronomic response of plants. The low repeatability is because genotypes behaved distinctively during these harvests (before physiological maturity and during dry season), reducing the correlation between harvests, and, consequently, repeatability.

In relation to LDM the combinations that presented the highest coefficients of repeatability and determination also included harvests 6 to 7 (Table 2). Satisfactory results were also observed when considering the combination of harvests 5 to 7 by the ANOVA method, with values of 0.599 and 81.79 , for the coefficients of repeatability and determination, 
Table 2. Number of harvests $(\mathrm{N})$, coefficient of repeatability and coefficient of determination (in brackets) of total dry mass (TDM), leaf dry mass (LDM) and leaf/stem ratio (LSR), considering different combinations among evaluations of Panicum maximum genotypes, according to the ANOVA and principal components based on the correlation matrix (PCCOR) methodologies.

\begin{tabular}{|c|c|c|c|c|c|c|c|}
\hline \multirow[b]{2}{*}{ Evaluation } & \multirow[b]{2}{*}{$\mathrm{N}$} & \multicolumn{2}{|c|}{ TDM } & \multicolumn{2}{|c|}{ LDM } & \multicolumn{2}{|c|}{ LSR } \\
\hline & & ANOVA & PCCOR & ANOVA & PCCOR & ANOVA & PCCOR \\
\hline $1-2$ & 2 & $0.268(42.31)$ & $0.275(43.12)$ & $0.288(44.67)$ & $0.289(44.75)$ & $0.379(55.01)$ & $0.869(92.99)$ \\
\hline $2-3$ & 2 & $0.639(77.99)$ & $0.708(82.91)$ & $0.609(75.73)$ & $0.618(76.37)$ & $0.000(0.00)$ & $0.028(5.44)$ \\
\hline $3-4$ & 2 & $0.191(32.14)$ & $0.228(37.19)$ & $0.304(46.67)$ & $0.407(57.83)$ & $0.088(16.24)$ & $0.532(69.42)$ \\
\hline $4-5$ & 2 & $0.378(54.87)$ & $0.417(58.84)$ & $0.377(54.80)$ & $0.465(63.50)$ & $0.448(61.84)$ & $0.520(68.44)$ \\
\hline $5-6$ & 2 & $0.604(75.28)$ & $0.679(80.87)$ & $0.626(77.00)$ & $0.692(81.78)$ & $0.085(15.70)$ & $0.093(17.13)$ \\
\hline $6-7$ & 2 & $0.697(82.17)$ & $0.719(83.64)$ & $0.666(79.96)$ & $0.703(82.58)$ & $0.813(89.67)$ & $0.839(91.23)$ \\
\hline $7-8$ & 2 & $0.560(71.79)$ & $0.568(72.43)$ & $0.535(69.69)$ & $0.541(70.22)$ & $0.008(1.64)$ & $0.014(2.71)$ \\
\hline $8-9$ & 2 & $0.272(42.73)$ & $0.328(49.42)$ & $0.337(50.42)$ & $0.430(60.12)$ & $0.000(0.00)$ & $0.200(33.32)$ \\
\hline $1-3$ & 3 & $0.344(61.11)$ & $0.392(65.93)$ & $0.379(64.68)$ & $0.397(66.35)$ & $0.172(38.38)$ & $0.435(69.78)$ \\
\hline $2-4$ & 3 & $0.268(52.29)$ & $0.390(65.72)$ & $0.298(55.98)$ & $0.423(68.74)$ & $0.032(9.08)$ & $0.284(54.40)$ \\
\hline $3-5$ & 3 & $0.350(61.72)$ & $0.421(68.60)$ & $0.408(67.37)$ & $0.553(78.81)$ & $0.255(50.66)$ & $0.365(63.25)$ \\
\hline $4-6$ & 3 & $0.317(58.22)$ & $0.435(69.82)$ & $0.309(57.34)$ & $0.471(72.77)$ & $0.000(0.00)$ & $0.308(57.17)$ \\
\hline $5-7$ & 3 & $0.565(79.58)$ & $0.624(83.28)$ & $0.599(81.79)$ & $0.646(84.55)$ & $0.367(63.51)$ & $0.426(69.01)$ \\
\hline $6-8$ & 3 & $0.555(78.90)$ & $0.589(81.15)$ & $0.527(76.97)$ & $0.539(77.81)$ & $0.380(64.81)$ & $0.420(68.51)$ \\
\hline $7-9$ & 3 & $0.409(67.52)$ & $0.425(68.89)$ & $0.433(69.63)$ & $0.492(74.42)$ & $0.157(35.89)$ & $0.221(46.04)$ \\
\hline $1-4$ & 4 & $0.246(56.61)$ & $0.298(62.95)$ & $0.274(60.10)$ & $0.349(68.22)$ & $0.001(0.19)$ & $0.322(65.57)$ \\
\hline $2-5$ & 4 & $0.371(70.22)$ & $0.472(78.14)$ & $0.402(72.89)$ & $0.549(82.98)$ & $0.167(44.46)$ & $0.244(56.42)$ \\
\hline $3-6$ & 4 & $0.341(67.39)$ & $0.465(77.64)$ & $0.371(70.19)$ & $0.544(82.67)$ & $0.002(1.01)$ & $0.301(63.31)$ \\
\hline $4-7$ & 4 & $0.353(68.63)$ & $0.480(78.70)$ & $0.352(68.53)$ & $0.513(80.84)$ & $0.061(20.67)$ & $0.384(71.39)$ \\
\hline $5-8$ & 4 & $0.503(80.20)$ & $0.551(83.07)$ & $0.511(80.72)$ & $0.539(82.38)$ & $0.234(55.00)$ & $0.284(61.04)$ \\
\hline $6-9$ & 4 & $0.476(78.43)$ & $0.514(80.85)$ & $0.478(78.52)$ & $0.531(81.91)$ & $0.357(68.99)$ & $0.406(73.23)$ \\
\hline $1-5$ & 5 & $0.344(72.44)$ & $0.413(77.90)$ & $0.358(73.64)$ & $0.463(81.18)$ & $0.124(41.49)$ & $0.250(62.52)$ \\
\hline $2-6$ & 5 & $0.379(75.35)$ & $0.519(84.39)$ & $0.397(76.69)$ & $0.576(87.15)$ & $0.012(5.68)$ & $0.289(67.00)$ \\
\hline $3-7$ & 5 & $0.363(74.05)$ & $0.479(82.13)$ & $0.385(75.79)$ & $0.533(85.11)$ & $0.048(20.15)$ & $0.343(72.32)$ \\
\hline $4-8$ & 5 & $0.422(78.48)$ & $0.498(83.24)$ & $0.397(76.69)$ & $0.511(83.93)$ & $0.063(25.18)$ & $0.303(68.53)$ \\
\hline $5-9$ & 5 & $0.445(80.06)$ & $0.493(82.96)$ & $0.457(80.82)$ & $0.510(83.88)$ & $0.264(64.19)$ & $0.310(69.21)$ \\
\hline $1-6$ & 6 & $0.355(76.76)$ & $0.462(83.74)$ & $0.364(77.43)$ & $0.502(85.82)$ & $0.049(23.84)$ & $0.365(77.54)$ \\
\hline $2-7$ & 6 & $0.399(79.91)$ & $0.525(86.88)$ & $0.410(80.65)$ & $0.563(88.53)$ & $0.051(24.39)$ & $0.391(79.38)$ \\
\hline $3-8$ & 6 & $0.411(80.72)$ & $0.484(84.93)$ & $0.411(80.71)$ & $0.518(86.55)$ & $0.055(25.80)$ & $0.333(74.94)$ \\
\hline $4-9$ & 6 & $0.375(78.28)$ & $0.454(83.28)$ & $0.350(76.35)$ & $0.478(84.60)$ & $0.113(43.35)$ & $0.295(71.47)$ \\
\hline $1-7$ & 7 & $0.360(79.77)$ & $0.464(85.81)$ & $0.366(80.19)$ & $0.492(87.16)$ & 0.091(41.09) & $0.453(85.27)$ \\
\hline $2-8$ & 7 & $0.419(83.45)$ & $0.507(87.80)$ & $0.417(83.36)$ & $0.527(88.62)$ & $0.056(29.45)$ & $0.335(77.93)$ \\
\hline $3-9$ & 7 & $0.376(80.84)$ & $0.450(85.16)$ & $0.371(80.52)$ & $0.488(86.98)$ & $0.095(42.28)$ & $0.315(76.27)$ \\
\hline $1-8$ & 8 & $0.372(82.60)$ & $0.453(86.87)$ & $0.375(82.73)$ & $0.470(87.65)$ & $0.090(44.16)$ & $0.388(83.53)$ \\
\hline $2-9$ & 8 & $0.388(83.52)$ & $0.473(87.80)$ & $0.383(83.23)$ & $0.498(88.83)$ & $0.089(44.07)$ & $0.326(70.44)$ \\
\hline $1-9$ & 9 & $0.350(82.89)$ & $0.430(87.16)$ & $0.350(82.87)$ & $0.453(88.15)$ & $0.113(53.33)$ & $0.370(84.10)$ \\
\hline
\end{tabular}

respectively. Satisfactory results were also observed by the PCCOR method with combinations of harvests 6 and 7 with repeatability values of 0.703 and determination value of 82.58 (Table 2). These harvests correspond to the evaluation period during the rainy season, thus the explanation of these best results. The combinations of harvests that presented the lowest coefficients of repeatability and determination were those that included the first harvests. Similar results were observed by Torres et al. (2016) in a work evaluating leaf dry mass in accessions of P. maximum, in which the lowest coefficients of repeatability and determination were also related to first harvests.

For the LSR characteristic, as observed for TDM and LDM, the best coefficients of repeatability (0.813) and determination (89.67) were recorded for harvests 6 to 7 by the ANOVA method (Table 2). These results can be explained by the fact that harvests occurred in the second year of the experiment during the rainy season, with homogeneous environmental conditions in relation to temperature and precipitation (Figure 1). It is noteworthy that the decrease in precipitation caused by a dry spell during the summer was much less expressive in the second year, which may have contributed to greater uniformity of environmental conditions.

By the PCCOR method, the highest coefficients of repeatability and determination for LSR were observed for the combinations between harvests 1 and 2 (Table 2). During the initial growth phase, plants present a greater amount of 
leaves in relation to stems when compared with already established plants. This is because harvests 1 and 2 were carried out in February and March, when high temperatures and precipitation occur, resulting in favorable conditions for the better development of plants, thus, all these factors may have contributed to the best results found related to these combinations of harvests. The higher coefficients of repeatability and determination for harvests 1 and 2 by the PCCOR method may also be explained by the fact that harvests evaluated two by two are more similar to each other than among more harvests, besides this method taking into account the cyclic behavior presented by the genotypes.

It should be emphasized that the evaluation in only two successive cuts may not represent the condition of greater genotypic stabilization, but rather the occurrence of two very similar harvests. Therefore, periods that include more cuts should be preferred to determine the stabilization of the genotypes, as observed in the harvests from 5 to 8 for TDM.

The analysis of the genotypic stabilization of $\mathrm{L} \%$ showed that the best repeatability coefficients observed were also related to harvests 6 and 7 by the ANOVA method, and the same behavior was observed in PCCOR (Table 3). Evaluations that included first to fourth harvests, mostly decreased the repeatability values, possibly because plants were not stabilized in the first harvests, showing the need to make evaluations during all the cycles of development of plants, since variations in responses of establishment phase to the effective production stage occur (Pereira et al., 2002).

Table 3. Number of harvests $(\mathrm{N})$, coefficient of repeatability and coefficient of determination (in brackets) of dry mass of stem (SDM), leaf percentage ( $(\mathrm{L} \%)$ and stem percentage $(\mathrm{S} \%)$, considering different combinations between harvests carried out in Panicum maximum genotypes according to the ANOVA and principal components based on the correlation matrix (PCCOR) methodologies.

\begin{tabular}{|c|c|c|c|c|c|c|c|}
\hline \multirow[b]{2}{*}{ Evaluation } & \multirow[b]{2}{*}{$\mathrm{N}$} & \multicolumn{2}{|c|}{ SDM } & \multicolumn{2}{|c|}{$\mathrm{L} \%$} & \multicolumn{2}{|c|}{$\mathrm{S} \%$} \\
\hline & & ANOVA & PCCOR & ANOVA & PCCOR & ANOVA & PCCOR \\
\hline $1-2$ & 2 & $0.128(22.73)$ & $0.144(25.13)$ & $0.479(64.79)$ & $0.479(64.79)$ & $0.449(61.98)$ & $0.452(62.24)$ \\
\hline $2-3$ & 2 & $0.474(74.31)$ & $0.479(64.78)$ & $0.025(4.81)$ & $0.029(5.57)$ & $0.000(0.00)$ & $0.069(12.96)$ \\
\hline $3-4$ & 2 & $0.000(0.00)$ & $0.065(12.29)$ & $0.467(63.70)$ & $0.515(67.97)$ & $0.508(67.36)$ & $0.531(69.35)$ \\
\hline $4-5$ & 2 & $0.000(0.00)$ & $0.165(28.32)$ & $0.048(9.09)$ & $0.079(14.69)$ & $0.000(0.00)$ & $0.265(41.94)$ \\
\hline $5-6$ & 2 & $0.441(61.16)$ & $0.586(73.86)$ & $0.440(61.11)$ & $0.440(61.11)$ & $0.614(76.06)$ & $0.620(76.55)$ \\
\hline $6-7$ & 2 & $0.655(79.15)$ & $0.672(80.35)$ & $0.683(81.18)$ & $0.685(81.34)$ & $0.705(82.72)$ & $0.710(83.03)$ \\
\hline $7-8$ & 2 & $0.227(37.03)$ & $0.320(48.53)$ & $0.000(0.00)$ & $0.097(17.68)$ & $0.255(40.67)$ & $0.284(44.22)$ \\
\hline $8-9$ & 2 & $0.060(11.37)$ & $0.368(53.81)$ & $0.000(0.00)$ & $0.225(36.75)$ & $0.168(28.77)$ & $0.245(39.39)$ \\
\hline $1-3$ & 3 & $0.232(47.58)$ & $0.248(49.72)$ & $0.085(21.73)$ & $0.240(48.64)$ & $0.040(11.11)$ & $0.237(48.27)$ \\
\hline $2-4$ & 3 & $0.121(29.17)$ & $0.380(64.82)$ & $0.094(23.69)$ & $0.361(62.85)$ & $0.046(12.58)$ & $0.432(69.53)$ \\
\hline $3-5$ & 3 & $0.000(0.00)$ & $0.086(21.99)$ & $0.253(50.47)$ & $0.279(53.71)$ & $0.161(36.55)$ & $0.308(57.19)$ \\
\hline $4-6$ & 3 & $0.069(18.25)$ & $0.373(64.05)$ & $0.000(0.00)$ & $0.271(52.72)$ & $0.000(0.00)$ & $0.447(70.77)$ \\
\hline $5-7$ & 3 & $0.463(72.15)$ & $0.579(80.50)$ & $0.535(77.52)$ & $0.538(77.72)$ & $0.657(85.16)$ & $0.661(85.43)$ \\
\hline $6-8$ & 3 & $0.293(55.40)$ & $0.489(74.14)$ & $0.131(31.21)$ & $0.343(61.01)$ & $0.336(60.30)$ & $0.440(70.20)$ \\
\hline $7-9$ & 3 & $0.147(34.10)$ & $0.326(59.23)$ & $0.000(0.00)$ & $0.132(31.39)$ & $0.267(52.19)$ & $0.373(64.08)$ \\
\hline $1-4$ & 4 & $0.082(26.27)$ & $0.266(59.24)$ & $0.011(4.26)$ & $0.360(69.26)$ & $0.000(0.00)$ & $0.388(71.72)$ \\
\hline $2-5$ & 4 & $0.100(30.90)$ & $0.280(60.87)$ & $0.093(29.16)$ & $0.240(55.87)$ & $0.012(4.54)$ & $0.350(68.31)$ \\
\hline $3-6$ & 4 & $0.021(8.01)$ & $0.253(57.57)$ & $0.109(32.97)$ & $0.251(57.22)$ & $0.060(20.27)$ & $0.357(68.96)$ \\
\hline $4-7$ & 4 & $0.149(41.21)$ & $0.462(77.48)$ & $0.000(0.00)$ & $0.409(73.46)$ & $0.000(0.00)$ & $0.540(82.45)$ \\
\hline $5-8$ & 4 & $0.299(63.03)$ & $0.465(77.67)$ & $0.182(47.05)$ & $0.358(69.09)$ & $0.373(70.41)$ & $0.483(78.92)$ \\
\hline $6-9$ & 4 & $0.225(53.79)$ & $0.485(79.03)$ & $0.047(16.64)$ & $0.243(56.21)$ & $0.353(68.55)$ & $0.506(80.37)$ \\
\hline $1-5$ & 5 & $0.133(43.48)$ & $0.279(65.95)$ & $0.052(21.51)$ & $0.301(68.25)$ & $0.011(5.20)$ & $0.394(76.45)$ \\
\hline $2-6$ & 5 & $0.121(40.84)$ & $0.317(69.92)$ & $0.054(22.39)$ & $0.310(69.25)$ & $0.006(3.10)$ & $0.411(77.69)$ \\
\hline $3-7$ & 5 & $0.076(29.23)$ & $0.355(73.33)$ & $0.068(26.88)$ & $0.328(70.90)$ & $0.033(14.57)$ & $0.430(79.04)$ \\
\hline $4-8$ & 5 & $0.147(46.22)$ & $0.404(77.21)$ & $0.020(9.10)$ & $0.307(68.92)$ & $0.000(0.00)$ & $0.431(79.12)$ \\
\hline $5-9$ & 5 & $0.244(61.80)$ & $0.453(80.55)$ & $0.114(39.17)$ & $0.284(66.50)$ & $0.380(75.43)$ & $0.514(84.10)$ \\
\hline $1-6$ & 6 & $0.148(50.96)$ & $0.325(74.32)$ & $0.048(23.27)$ & $0.373(78.09)$ & $0.023(12.55)$ & $0.446(82.84)$ \\
\hline $2-7$ & 6 & $0.150(51.42)$ & $0.379(78.55)$ & $0.052(24.66)$ & $0.373(78.15)$ & $0.017(9.31)$ & $0.457(83.47)$ \\
\hline $3-8$ & 6 & $0.181(57.03)$ & $0.348(76.19)$ & $0.121(45.21)$ & $0.277(69.79)$ & $0.095(38.71)$ & $0.352(76.56)$ \\
\hline $4-9$ & 6 & $0.132(47.62)$ & $0.399(79.93)$ & $0.031(16.35)$ & $0.252(66.86)$ & $0.024(12.76)$ & $0.454(83.32)$ \\
\hline $1-7$ & 7 & $0.169(58.78)$ & $0.370(80.47)$ & $0.059(30.46)$ & $0.415(83.23)$ & $0.042(23.62)$ & $0.483(86.75)$ \\
\hline $2-8$ & 7 & $0.222(66.70)$ & $0.380(81.07)$ & $0.105(45.18)$ & $0.311(75.98)$ & $0.085(39.47)$ & $0.397(82.19)$ \\
\hline $3-9$ & 7 & $0.159(57.03)$ & $0.350(79.03)$ & $0.095(42.45)$ & $0.239(68.73)$ & $0.098(43.33)$ & $0.382(81.22)$ \\
\hline $1-8$ & 8 & $0.217(68.97)$ & $0.362(81.93)$ & $0.105(48.47)$ & $0.356(81.57)$ & $0.097(46.37)$ & $0.430(85.77)$ \\
\hline $2-9$ & 8 & $0.197(66.19)$ & $0.365(82.15)$ & $0.080(40.92)$ & $0.267(74.43)$ & $0.092(44.93)$ & $0.407(84.60)$ \\
\hline $1-9$ & 9 & $0.195(68.61)$ & $0.351(82.94)$ & $0.085(45.60)$ & $0.312(80.33)$ & $0.105(51.41)$ & $0.433(87.29)$ \\
\hline
\end{tabular}


As for the other characteristics, the combination between harvests 6 to 7, which were performed on 2 February and 14 March 2016, provided higher coefficients of repeatability and determination for S\% and SDM, both for ANOVA as well as for PCCOR (Table 3). In fact, when climatic conditions are favorable, there is a better development of each plant, including stems. For $\mathrm{S} \%$, a small increase was observed with the harvests 5 to 7 , which corresponded exactly to the three harvests in the rainy season of the second year of evaluation. The other coefficients of repeatability, involving other combinations among the nine harvests, were generally low, which indicates great variation of this characteristic and its low potential for evaluation in breeding programs, with a focus on the negative selection.

The SDM presented coefficients greater than S\%, despite its variation found (Table 3), which should reflect the greater ease of measurement of SDM. In this sense, variation in the weight of stems accumulated along a harvest may have been smaller than its relative participation in the total forage production.

Values equal to zero were observed for the characteristics LSR, L\%, S\%, and SDM by the ANOVA method (Tables 2 and 3), and the combinations between harvests that stood out the most were 4 to 6 for LSR, L\% and S\%. Zero repeatability means absence of relationship between repeated measures and genotypic variance for the period.

\section{CONCLUSIONS}

The methods that provided the best coefficients of determination and repeatability were those of the major components based on the correlation and covariance matrices.

The characteristics leaf dry mass and total dry mass presented high coefficients of repeatability and determination, indicating reliability in the identification of the best Panicum maximum genotypes.

The characteristics leaf percentage, stem percentage, stem dry mass and leaf:stem ratio, present great variations among the evaluated methods, nevertheless, the repeatability coefficients were considered low.

For the genotypic stabilization, the best coefficients of repeatability and determination were observed for harvests performed in the second rainy period (from 5 to 8). Harvests performed before plants acquire physiological maturity and during dry season are detrimental in the selection process due to low repeatability.

\section{ACKNOWLEDGEMENTS}

This study was financed in part by the Coordenação de Aperfeicoamento de Pessoal de Nível Superior - Brasil (CAPES) - finance code 001. The authors also would like to thank Pró-reitoria de Pesquisa e Pós-graduação from Universidade Federal de Minas Gerais for the financial support.

\section{REFERENCES}

Abeywardena, V. 1972. An application of principal component analysis in genetics. Journal of Genetics 61:27-51.

Braz, T.G.S., Fonseca, D.M., Jank, L., Cruz, C.D., and Martuscello, J.A. 2015b. Repeatability of agronomic traits in Panicum maximum (Jacq.) hybrids. Genetics and Molecular Research 14:19282-19294.http://dx.doi.org/10.4238/2015.December.29.38 .

Braz,T.G.S.,Fonseca,D.M.,Jank,L.,Cruz,C.D., and Martuscello, J.A. 2015a. Genotypic stabilization of agronomic traits in Panicum maximum (Jacq.) hybrids. Revista Brasileira Zootecnia 44:377-383. http://dx.doi.org/10.1590/S1806-92902015001100001.

Cargnelutti Filho, A., Castilhos, Z.M., Storck, L., e Savina, J.F. 2004. Análise de repetibilidade de caracteres forrageiros de genótipos de Panicum maximum, avaliados com e sem restrição solar. Ciência Rural 34:723-729. http://dx.doi.org/10.1590/S0103-84782004000300011.

Cruz, C.D. 2013. GENES - a software package for analysis in experimental statistics and quantitative genetics. Acta Scientiarum. Agronomy 35:271-276. http://dx.doi.org/10.4025/actasciagron.v35i3.21251.

Cruz, C.D., Regazzi, A.J., e Carneiro, P.C.S. 2004. Modelos biométricos aplicados ao melhoramento genético. Vol. 1. Editora UFV, Viçosa, Minas Gerais, Brasil.

Fernandes, F.D., Braga, G.J., Ramos, A.K.B., Jank, L., Carvalho, M.A., Maciel, G.A., et al. 2017. Repeatability, number of harvests, and phenotypic stability of dry matter yield and quality traits of Panicum maximum Jacq. Acta Scientiarum. Animal Sciences 39:149-155. http://dx.doi.org/10.4025/actascianimsci.v39i2.32915.

Fernandes, F.D., Ramos, A.K.B., Jank, L., Carvalho, M.A., Martha Jr., G.B., and Braga, G.J. 2014. Forage yield and nutritive value of Panicum maximum genotypes in the Brazilian savannah. Scientia Agricola 71:23-29. http://dx.doi.org/10.1590/S0103-90162014000100003. 
Freitas, F.P., Fonseca, D.M., Braz, T.G.S., Martuscello, J.A., and Santos, M.E.R. 2012. Forage yield and nutritive value of Tanzania guinea grass under nitrogen supplies and plant densities. Revista Brasileira de Zootecnia 41:864-872. http://dx.doi.org/10.1590/S1516-35982012000400006.

Jank, L., Barrios, S.C., do Valle, C.B., Simeão, R.M., and Alves, G.F. 2014. The value of improved pastures to Brazilian beef production. Crop and Pasture Science 65(11):1132-1137. https://doi.org/10.1071/CP13319.

Jank, L., Valle, C.D., and Resende, R.M.S. 2011. Breeding tropical forages. Crop Breeding and Applied Biotechnology S1:2734. http://dx.doi.org/10.1590/S1984-70332011000500005.

Lédo, F.J.S., Pereira, A.V., Souza Sobrinho, F., Auad, A.M., Jank, L., e Silva e Oliveira, J. 2008. Estimativas de repetibilidade para caracteres forrageiros em Panicum maximum. Ciência e Agrotecnologia 32:1299-1303.

Mansour, H., Nordheim, E.V., and Rutledge, J.J. 1981. Estimators of repeatability. Theoretical and Applied Genetics 60:151-156.

Martuscello, J.A., Jank, L., Fonseca, D.M., Cruz, C.D., e Cunha, D.N.F.V. 2007. Repetibilidade de caracteres agronômicos em Panicum maximum Jacq. Revista Brasileira de Zootecnia 36:1975-1981 . http://dx.doi.org/10.1590/S1516-35982007000900005.

Pereira, A.V., Cruz, C.D., Ferreira, R.P., Botrel, M.A., e Oliveira, J.S. 2002. Influência da estabilização de genótipos de capim elefante (Pennisetum purpureum Schum.) sobre a estimativa da repetibilidade de características forrageiras. Ciência e Agrotecnologia 26:762-767.

Souza Sobrinho, F., Borges, V., Lédo, F.J.S., e Kopp, M.M. 2010. Repetibilidade de características agronômicas e número de cortes necessários para seleção de Urochloa ruziziensis. Pesquisa Agropecuária Brasileira 45:579584. http://dx.doi.org/10.1590/S0100-204X2010000600007.

Torres, F.E., Teodoro, P.E., Benites, S.B., Oliveira, E.F., Corrêa, C.C.G., and Silva, F.A. 2016. Number of harvests for estimating forage productivity in Panicum maximum. Bioscience Journal 32:172-178. http://dx.doi.org/10.14393/BJ-v32n1a2016-29307.

Valle, C.B., Jank, L., e Resende, R.M.S. 2009. O melhoramento de forrageiras tropicais no Brasil. Revista Ceres 56:460-472. 